Original Paper

\title{
Sosialisasi dan Pendampingan Pengembangan Instrumen Hasil Belajar Berbasis Ketrampilan Berpikir Tingkat Tinggi (HOTS) pada Mahasiswa Magister Pendidikan IPA Universitas Mataram
}

\author{
Wildan $^{1 *}$, Aliefman Hakim ${ }^{1}$, Dwi Laksmiwati ${ }^{1}$, Lalu Rudyat Telly Savalas ${ }^{1}$, dan \\ Supriadi $^{1}$
}

${ }^{1}$ Program Studi Pendidikan Kimia, Fakultas Keguruan dan Ilmu Pendidikan, Universitas Mataram, Indonesia

DOI: $10.29303 /$ jpmpi.v2i1.335

Sitasi: Wildan, et, al. (2019). Sosialisasi dan Pendampingan Pengembangan Instrumen Hasil Belajar Berbasis Ketrampilan Berpikir Tingkat Tinggi (HOTS) pada Mahasiswa Magister Pendidikan IPA Universitas Mataram. Jurnal Pengabdian Magister Pendidikan IPA (JPMPI). (2) 1. pp. 28-33

*Corresponding Author: Wildan, Program Studi Pendidikan Kimia, Fakultas Keguruan dan Ilmu Pendidikan, Universitas Mataram, Indonesia; Email: wildanfkip@unram.ac.id

\begin{abstract}
Abstrak: Tujuan kegiatan pengabdian masyarakat ini adalah untuk meningkatkan pemahaman dan kemampuan mahasiswa Magister Pendidikan Ilmu Pengetahuan Alam Universitas Mataram dalam mengembangkan instrumen hasil belajar berdasarkan keterampilan berpikir tingkat tinggi. Kegiatan ini dilakukan dengan beberapa metode, yaitu ceramah, pertanyaan dan jawaban, latihan singkat dan diskusi terfokus. Kegiatan diakhiri dengan evaluasi untuk mendapatkan gambaran umum proses dan hasil kegiatan. Pengumpulan data dilakukan melalui kuesioner, wawancara, dan diskusi. Berdasarkan hasil pengumpulan data, dapat disimpulkan bahwa kegiatan berjalan dengan baik, hasilnya sangat bermanfaat bagi peserta, dan akan ditindaklanjuti dengan latihan untuk mengembangkan tes hasil pembelajaran berbasis HOTS yang sesuai dengan tuntutan kurikulum 2013. Hambatan dalam mengembangkan hasil pembelajaran berbasis HOTS termasuk kemampuan yang tidak memadai dan tugas administrasi dan akademik yang berat.
\end{abstract}

Kata kunci: Pembelajaran IPA, Hasil Belajar, HOTS.

\section{Pendahuluan}

Ketrampilan berpikir tingkat tinggi (high order thinking skill) merupakan kebutuhan yang harus dimiliki oleh setiap individu pada era globalisasi. Dalam Kurikulum 2013, menuntut kepada guru/dosen mengembangkan pembelajaran dan evaluasi berbasis HOTS dengan harapan agar peserta didik memiliki daya dalam membangun kerangka berpikir kritis, analitis.

Pengembangan kemampuan berpikir kritis, analitis hanya dapat dilakukan melalui proses belajar berpikir kritis. Proses belajar berpikir kritis yaitu siswa belajar dari pengalaman sendiri, mengkonstruksi pengetahuan kemudian memberi makna pada pengetahuan itu, sehingga berpikir kritis menjadi suatu keharusan yang harus di dapatkan siswa dalam belajarnya.
Ketrampilan berpikir tingkat tinggi meliputi kemampuan pemecahan masalah, kemampuan berpikir kreatif, kemampuan berpikir kritis, kemampuan berargumen, dan kemampuan mengambil keputusan. Saputra (2016). Hal yang sama disebutkan Cotton (1993), bahwa ketrampilan berpikir tingkat tinggi mencakup problem solving, learning skills: strategies, creative: innovative thinking, dan decision making. Ketrampilan berpikir tingkat tinggi mencakup pemahaman (comprehension), pemecahan masalah (problem solving) berpikir kritis (critical thinking), dan memberi alasan praktis (pratical reasoning). Thomas dan Litowits (1986) menyatakan bahwa pemahaman merupakan pondasi dasar dari proses berpikir yang lebih tinggi.

Meskipun kurikulum 2013 telah berlaku kurang lebih enam tahun dengan berbagai kebijakan dan diikuti pedoman pelaksana-annya, 
namun sebagian besar guru (IPA) belum banyak mengembangkan pembela-jaran dan evaluasinya berbasis HOTS dengan berbagai alasan. Dari hasil observasi dan wawancara terhadap mahasiswa/guru, HOTS sekedar ditungkan dalam Rencana Persiapan Pembelajaran (RPP), belum dilaksanakan dalam pembelajaran dan evaluasi, karena pemahaman dan kemampuannya yang belum memadai.

Hasil analisis kebutuhan di sekolah mendapatkan kesimpulan bahwa guru membutuhkan instrumen evaluasi yang mampu mengukur keterampilan berpikir tingkat tinggi. (Wildan, dkk. 2018). Hasil wawancara dengan beberapa guru kimia di Lombok Barat didapatkan bahwa sebagian besar guru kimia masih kesulitan dalam mengembangkan instrumen untuk mengukur kemampuan berpikir kritis dan ketrampilan berpikir tingkat tinggi siswa. Hal ini disebabkan karena mereka sudah merasa cukup dengan alat evaluasi pilihan ganda biasa. Selain itu, mereka juga belum pernah mempelajari cara mengembangkan instrumen tersebut.

Dalam melakukan evaluasi pembelajaran, sebagian besar guru mengandalkan tes dalam bentuk pilihan ganda biasa. Soal pilihan ganda digunakan karena penilaian soal lebih objektif dan penskorannya mudah, tetapi kemungkinan siswa untuk menebak jawaban atau menjawab soal secara untung-untungan sangat besar. Soal pilihan ganda juga kurang mampu mengukur kemampuan kognitif yang lebih tinggi (Nofiana, et al., 2014).

Sebagian guru yang mempunnyai pemahaman dan kemampuan yang memadai, seringkali tidak diberdayagunakan dalam memahami kemampuan kognitif siswa, sehingga pembelajaran hanya mengan-dalkan sebuah istilah "yang penting pembelajaran ada". Peningkatan pengha-yatan melalui peningkatan pemahaman dan kemampuan guru tentang pembelajaran dan evaluasi yang bermakna bagi muridnya harus terus dilakukan dengan serius.

Berdasarkan uraian di atas, salah satu kemampuan guru yang sangat dibutuhkan adalah kemampuan mengembangkan instrumen penilaian berbasis HOTS. Dengan instrumen penilaian seperti itu diharapkan dapat membelajarkan dan membiasakan siswa berpikir kritis, analitis dalam menye-lesaian suatu masalah.Instrumen penilaian yang dapat mengukur kemampuan siswa secara objektif dan dapat digunakan sebagai alat evaluasi bagi siswa untuk mengetahui batas kemampuannya (Mulyono, 2008).

Utomo dan Kees Ruijter (1989) menyebutkan bahwa kesalahan yang sering terjadi pada siswa/guru dalam menjawab suatu soal/masalah antara lain (1) Kurang menganalisis soal, meliputi tidak membaca soal secara seksama, tidak menyadari apa yang diketahui, tidak menyadari apa yang ditanyakan, terlalu cepat dengan melakukan hitungan dengan rumus-rumus yang dihafal. (2) Tidak merencanakan jalan penyelesaian meliputi tidak mulai dari yang ditanyakan, tidak mengetahui persamaan yang terpenting, tidak menghubungkan teori umum dengan soal khusus yang dihadapi, (3) Tidak menyelesaikan soal secara rinci, mengabaikan satuan yang digunakan, terlalu awal mulai dari hitungan, tidak menilai lagi kebenaran jawaban, tidak memeriksa ulang jawaban yang sudah diperoleh. Kesalahan-kesalahan tersebut di atas terjadi karena siswa/mahasiswa tidak pernah diajar oleh guru/dosen. Hal tersebut sesuai dengan hasil pengamatan terhadap mahasiswa/guru IPA pada berbagai jenjang pendidikan (SD/SMP/SMA). Fungsi guru adalah sebagai fasilitator dan motivator yang mengembangkan kemampuan berpikir siswa, baik kemampuan berpikir kritis maupun kemampuan berpikir tingkat tinggi (Wildan, et al., 2018).

Keterampilan berpikir kritis siswa perlu diukur dengan alat ukur tes yang sesuai. Instrumen tes yang baik dapat meningkatkan kualitas hasil penilaian. Instrumen evaluasi yang mengukur keterampilan berpikir tingkat tinggi dapat menggunakan berbagai tipe penilaian seperti modified multiple choice, konstruksi jawaban singkat, dan konstruksi jawaban panjang seperti yang telah dilakukan oleh Ramirez (2008).

Berdasarkan hal tersebut, penulis tertarik untuk melakukan sosialisasi dan pendampingan penyusunan instrumen peni-laian berbasis HOTS untuk mahasiswa program Magister pendidikan IPA Universitas Mataram. Kegiatan ini merupakan bentuk intervensi dalam upaya meningkatkan ketrampilan berpikir kritis dan kemampuan berpikir tingkat tinggi.

\section{Metode Pelaksanaan}

Kegiatan sosialisasi dan pendampingan pengembangan instrumen penilaian berbasis HOTS dilakukan hanya sehari $( \pm 5$ jam $)$ Kegiatan yang 
dilakukan diruang kelas Pascasarjana Unram ini menggunakan metode ceramah, tanya jawab, latihan, dan diskusi terfokus (FGD) dengan media utama LCD dan hardcopy power point.

Pada kegiatan ini juga dilakukan pendampingan untuk menelaah dan berlatih mengembangkan soal berbasis HOTS untuk bidang studi kimia, fisika, dan biologi. Pada akhir kegiatan dilakukan pengumpulan data tentang proses dan hasil kegiatan dengan menggunakan kuesioner, wawancara, dan hasil latihan. Metode pelaksanaan kegiatan, adalah (1) Metode ceramah, Metode ini digunakan untuk memantapkan konsep dan prinsip pengembangan instrumen hasil belajar IPA berbasis HOTS, Media yang digunakan adalah LCD dan setiap peserta memperoleh ringkasan materi yang disampaikan oleh masing-masing penyaji. (2) Metode Tanya Jawab, pada saat berlangsung penyampaian materi oleh setiap pemateri dan setelah berlangsung penyampaian materi. (3) Diskusi terfokus (FGD) dan Pendampingan; Tim membagikan lembarkerja yang berisi tentang tuntunan dalam mengembangkan instrumen berbasis HOTS. Pada akhir diskusi, dilakukan diskusi pleno, satu kelompok menyampaikan hasilnya, dan kelompok lain menanggapi.

Materi yang disampaikan meliputi, (a) Konsep dan prinsip pengembangan instrumen hasil belajar IPA; (b) Konsep HOTS dan penerapannya dalam tes hasil belajar; (c) Konsep dan contoh Penyelesaian Soal Secara Bersistem (d) contohcontoh instrumen kemampuan berpikir tingkat tinggi. Pada akhir kegiatan dilakukan pengumpulan data dengan kuesioner, wawancara untuk mendapatkan tanggapan peserta tentang proses dan hasil kegiatan.

\section{Hasil dan Pembahasan}

Kegiatan sosialisasi dan pendampingan Pengembangan Instrumen Berbasis HOTS dilaksanakan selama sehari, pada Hari Sabtu, tanggal 28 September 2019 di Ruang Kuliah Pascasarjana Universitas Mataram, diikuti oleh 34 orang mahasiswa S-2 Pendidikan Sains Universitas Mataram, dan dihadiri oleh semua anggota tim.

Kegiatan diawali pada jam 09.00 dengan acara pembukaanyang disampaikan oleh Ketua Tim (Dr. H. Wildan). Pada acara pembukaan tersebut disampaikan tentang latar belakang, tujuan, manfaat, dan rangkaian acara pada kegiatan sosialisai/pendampingan. Setelah diselingi dengan acara kudapan/coffee break, acara dilanjutkan dengan penyanjian materi yang pertama, yaitu Pengembangan Instrumen Hasil Belajar oleh Ketua Tim. Adapun pokok materinya meliputi tahaptahap pengembangan instrumen tes hasil belajar, contoh-contoh soal pada bidang Kimia, Fisika, Biologi yang berbasis HOTS, kemudian Tanya jawab, dan kepada peserta diminta untuk menulis 2 contoh soal hasil belajar yang biasa mereka susun. Dari contoh-contoh yang dihasilkan peserta, diambil masing-masing 2 contoh dari setiap bidang studi untuk dibahas/didiskusikan agar menjadi test yang mengukur hasil belajar tingkat tinggi.

Kegiatan selanjutnya adalah penyampaian materi dan diskusi tentang Keterampilan Berpikir Tingkat Tinggi (HOTS) yang dipandu oleh Dr. Aliefman dan Dr. Lalu R. Telly S. Adapun pokokpokok materinya meliputi latar belakang keharusan guru membelajarkan siswanya untuk mencapai HOTS, konsep-konsep dasar (teori) HOTS, bagaimana HOTS, dan pengembangannya dalam pembelajaran. Pada kegiatan ini diakhiri dengan diskusi dan tanya jawab tentang HOTS pada masing-masing bidang studi IPA. Setelah dilaksanakan 2 kegiatan tersebut di atas, peserta dan narasumber istirahat selama 90 menit untuk sholat dan makan siang bersama.

Pada sesi ke 3, dimulai jam 14.00 - 16.00 disampaikan materi tentang Penyelesaian Soal Secara Bersistem (PSSB). Pada awal pertemuan peserta diminta menjawab 2 buah soal untuk masing-masing bidang studi dengan kesukaran soal rendah (diambil dari soal SMP dan SMA). Dari hasil jawaban peserta terhadap soal yang diajukan, semuanya benar, tapi dari segi proses cara menjawab soal semua salah.

Dari hasil tersebut, dilakukan identifikasi tentang kesalahan cara menjawab soal dan cara yang salah tersebut ditularkan kepada siswanya. Kesalahan-kesalahan dalam menyelesaiakan soal sebagai hasil diskusi tersebut antara lain, (1) kurang menganalisis soal dengan benar, seperti tidak membaca soal secara seksama, tidak menyadari apa yang diketahui, terlalu cepat melakukan hitungan dengan rumus-rumus yang dihafal,dan (2) tidak merenca-nakan jalan penyelesaian meliputi tidak mulai dari yang ditanyakan, tidak mengetahui persamaan yang terpenting, tidak menghubungkan teori umum dengan soal khusus yang dihadapi, tidak menyelesaikan soal secara rinci, dan mengabaikan satuan yang digunakan. 
Berdasarkan hasil diskusi di atas narasumber menyampaikan konsep dasar PSSB yang meliputi, (1) analisis, (2) perencanaan, (3) penyelesaian, dan (4) pemeriksaan dengan contoh-contohnya. Selanjutnya peserta diminta menjawab soal-soal yang diberikan pada awal pertemuan dengan cara PSSB. Pada akhir kegiatan ditutup oleh Ketua Tim dengan menyampaikan beberapa harapan kepada peserta antara lain mulai belajar mengembangkan tes hasil belajar tingkat tinggi (HOTS) dan belajar untuk menerapkan PSSB dalam menjawab soal mulai dari soal yang mudah. PSSB bukan hanya untuk menjawab soal pada bidang studi tertentu tapi dapat diterapkan pada masalah-masalah dalam kehidupan sehari-hari, "Penyelesaian suatu masalah, tidak jauh dari masalah tersebut, untuk itu, sebelum menyelesaiakn masalah, kenalilah masalah tersebut dengan seksama".

Sebelum acara selesai, dilakukan evaluasi untuk mengetahui tanggapan peserta terhadap kegiatan sosialisasi/pendampingan dan evaluasi pembelajaran untuk mengetahui penerimaan peserta terhadap kegiatan tersebut. Instrumen yang digunakan berupa kuesioner yang terdiri dari 5 (lima) komponen, yaitu (1) materi sosialisai, (2)hasil, (3) tindak lanjut, (4) fasilitator, (5) waktu pelaksanaan. Dari 5 (lima) komponen tersebut tersusun 6 (enam) indikator dan dari indikator tersebut tersusun 15 butir pernyataan dan yang masing-masing disertai dengan 3 (tiga) opsi jawaban mulai dari 1 (kurang baik), 2 (cukup baik), 3 (sangat baik). Skor rata-rata diperoleh dengan menjumlahkan jawaban responden pada setiap butir dibagi jumlah respondennya. Selanjutnya skor ratarata pada setiap butir instrumen dalam satu indikator dijumlahkan kemudian dibagi jumlah butir pada indikator tersebut. Gambaran skor pada setiap butir dan indikator evaluasi dengan jumlah responden 32 pada kegiatan sosialisasi dan pendampingan tertera pada Tabel 1 .

Tabel 1. Hasil Evaluasi Sosialisasi

\begin{tabular}{lll}
\hline Komponen & Indikator & Nilai \\
\hline 1.Materi & 1. Kejelasan dan Kemudahan diikuti & 2.83 \\
& a. Pengembangan tes hasil belajar & 2.93 \\
& b. HOTS & 2.89 \\
& c. Penyelesaian Soal Secara Bersistem (PSSB & 2.67 \\
& 2. Manfaat materi bagi peserta & 2.81 \\
& a. Pengembangan tes hasil belajar & 2.89 \\
& b. HOTS & 2.89 \\
2. Penyelesaian Soal Secara Bersistem (PSSB & 2.67 \\
& 3. Menambah pemahaman tentang Materi: & 2.85 \\
& a. Pengembangan tes hasil belajar & 2.92 \\
3. Tindakil Lanjut & b. HOTS & 2.85 \\
& c. Penyelesaian Soal Secara Bersistem (PSSB) & 2.79 \\
& 4. Mempelajari/berlatih lebih lanjut tentang materi: & 2.70 \\
& a. Pengembangan tes hasil belajar & 2.78 \\
4. Fasilitator & b. HOTS & 2.70 \\
& c. Penyelesaian Soal Secara Bersistem (PSSB) & 2.63 \\
& 5. Kemampuan dan Penampilan & 2.89 \\
5. Waktu & a. Kemampuan/penguasaan materi & 2.90 \\
& b. Penampilan & 2.88 \\
& 6. Waktu/lama kegiatan & 2.78 \\
& a. Waktu pelaksanaan (hari libur) & 2.80 \\
& b. Lama pelaksanaan (sehari_ & 2.76 \\
& Rata-rata & 2.83 \\
\hline
\end{tabular}

$\mathrm{N}=32$ peserta

Dari tabel di atas dapat diketahui bahwa skor penilaian secara keseluruhan 2,83 pada rentangan skor 1 (kurang baik) - 3 (sangat baik). Dari hasil tersebut dapat disimpulkan bahwa kegiatan sosialisasi dan pendampingan pengembangan instrumen hasil belajar IPA berbasis HOT masuk dalam katagori sangat baik. 
Pada komponen materi yang terdiri dari 2 (dua) indikator yaitu kejelasan dan manfaat materi bagi peserta. Untuk kejelasan materi yang terdiri dari 3 butir pernyataan sebagian besar menjawab pada skala 3 (sangat baik) dengan nilai rata-rata 2,83 . Demikian juga dengan indikator manfaat materi, nilai rata-rata 2.81. Berdasarkan hal tersebut ketiga materi meliputi (a). Pengembangan tes hasil belajar, (b). HOTS, dan (c) Penyelesaian Soal Secara Bersistem (PSSB) sangat jelas dan mudah dipahami dan sangat bermanfaat bagi mereka. Materi pengembangan tes hasil belajar dan HOTS tersebut bagi sebagian peserta sudah sangat familiar, karena sebagian peserta adalah guru yang sudah sering mendapatkan informasi baik melaui kuliah maupun pelatihan. Materi PSSB oleh sebagian peserta, kurang familiar, meskipun materi tersebut sudah lama dikembangkan di perguruan tinggi melalui kegiatan Applied Aproach (AA). Di tingkat pendidikan menengah, keterampilan PSSB ini dikembangkan sebagai jenis materi pembelajaran dengan keterampilan menyelesaikan masalah, terutama dalam pembelajaran matematika. PSSB ini, bagian dari materi pembelajaran yang harus dikembangkan dalam kurikulum 2013 dan dikenal dengan istilah " pengetahuan matakognisi", sehingga materi PSSB mungkin masih asing/belum familiar oleh sebagian peserta.

Hal di atas, kemungkinan menjadi penyebab skor pada materi PSSB agak rendah dibanding dua materi lainya. Hal tersebut sesuai hasil hasil pendampingan, hampir semuanya peserta masih salah dalam menerapkan PSSB, peserta kenal dalam mengerjakan soal, ditulis dengan "Diketahui, Ditanyakan, dan Jawab". Kesalahan lain bagi peserta dalam menjawab soal, terlalu cepat menjawab dengan rumus tanpa membaca soal dengan seksama, dan sering mengbaikan satuansatuan yang diketahui maupun ditanyakan. Untuk membiasakan diri dalam menerapkan PSSB ketika menyelesaikan soal dibutuhkan latihan-latihan secara berkelanjutan dimulai dengan soal-soal yang mudah, sedang dan berlanjut ke soal-soal tingkat tinggi (HOTS).

Komponen kedua dalam evaluasi tersebut adalah pemahaman peserta tentang materi-materi sosialisasi dan pendampingan. Dari tabel di atas diperoleh nilai rata-rata 2.85 pada rentangan nilai 1 (kurang bermanfaat) - 3 (sangat bermanfaat). Sama dengan indikator sebelumnya, pada indikator manfaat materi, pada indikator PSSB memperoleh nilai terendah dibanding dua indikator lainnya.
PSSB akan sangat bermanfaat bilamana menghadapi soal-soal berbasis HOTS, dan membutuhkan ketrampilan yang diperoleh melalui latihan-latihan secara terus-menerus, mulai dari saol yang mudah ke soal yang lebih kompleks.

Hasil evaluasi pada komponen tindak lanjut dari kegiatan sosialisasi/pendampingan diperoleh nilai rata-rata 2.70 pada rentangan nilai $1-3$. Hasil ini menunjukkan bahwa peserta mempunyai niat dan tekad untuk berlatih dalam menyusun soal-soal HOTS pada bidang studinya masing-masing. Dengan kata lain peserta bersikap positif terhadap materi-materi yang disempaikan pada kegiatan sosialisai/pendampingan. Demikian pula penilaian peserta terhadap komponen lain, seperti kemampuan dan penampilan fasilitator, waktu pelaksanaan dan lama pelaksanaan, konsumsi dan lainnya. Di antara komponen tersebut, komponen waktu dan lama kegiatan memperoleh nilai paling rendah dibandingkan komponen yang lain. Hal tersebut dapat dipahami karena pelaksanaan kegiatan dilakukan sehari (dan dilaksanakan pada waktu hari libur di kampus.

Hasil kuesioner di atas, diperkuat dengan hasil wawancara dengan 3 (tiga) orang peserta yang mengatakan bahwa pada umumnya guru IPA sudah tahu tentang pengembangan instrumen hasil belajar dan konsep HOTS, tetapi belum dapat mengaplikasikan dengan baik, karena kemampuan yang belum memadai, tugas-tugas mempersipakan dokumen-dokumnen pembelajaran yang banyak dan beban tugas yang semakin berat. Pada materi PSSB, para guru menerapkannya dalam versi yang beda dan seringkali tidak melakukan penilaian terhadap semua langkah penyelesaian soal/masalah, akibatnya siswa pada semua tingkatan melakukan hal yang sama.

Terkait dengan indikator kemampuan dan penampilan narasumber, skor rata-rata 2,89, termasuk dalam katagori sangat mampu dan berpanampilan sangat baik, karena narasumber telah mempersiapkan materi dengan baik dengan power point yang menarik, dibantu handout. Mengenai waktu pelaksanaan juga demikian. Skor rata-rata 2,78 relatif lebih rendah penilaian peserta, terutama pada lama pelaksanaan yang hanya sehari. Dengan kata lain bila kegiatan sejenis dilakukan perlu waktu yang panjang panjang, minimal 2 (dua) hari 


\section{Kesimpulan}

Berdasarkan hasil tersebut di atas dapat disimpulkan bahwa (1) Kegiatan sosialisasi dan pendampingan pengem-bangan instrumen hasil belajar berbasis HOTS berjalan dengan baik dan lancar sesuai perencanaan; (2) Hasil kegiatan sangat positif bagi peserta, baik materi sosialisasi/pendampingan, pemahaman, kegunaan dan tindak lanjut yang akan dilakukan peserta. (3) Kendala peserta dalam menerapkan pengembangan instrumen berbasis HOTS bagi guru antara lain kemampuan yang masih belum mencukupi dan beban tugas administrasi yang tinggi dan beban tugas mengajar yang cukup padat.

\section{Saran}

Waktu dan lama pelaksanaan untuk kegiatan sejenis terutama perlu diperpanjang minimal 2 (dua) hari.

\section{Ucapan Terima Kasih}

Ucapan terima kasih disampaikan sebesarbesarnya kepada: 1) Ketua LPPM Universitas Mataram. 2) Dekan FKIP Universitas Mataram. 3) Ketua Program Studi Magister Pendidikan IPA dengan segenap jajarannya. 4) Para rekan Tim Pengabdian dari program studi Pendidikan Kimia.

\section{Daftar Pustaka}

Afandi \& Sajidan. (2017). Stimulasi Ketrampilam Berpikir Tingkat Tinggi: Konsep dan Implikasi Dalam Pembelajan Abad 21. Surakarta: UPT UNS Press

Aryati, Wuryandari \& Akmaliyah, M. (2016). Game Interaktif Mencegah Terjadinya Pemanasan Global untuk Anak. Jurnal SIMETRIS, 7 (1), 311-320.

Cotton, K. 1993. Developing Employability Skills dalam School Improvement Research Series. Research You Can Use. 52 Jurnal Pendidikan Karakter, III (1), Diakses pada tanggal 6 Januari 2012 dari http://www.nwrel.org/scpd/sirs/8/c015.ht $\underline{\mathrm{ml}}$.

Mufida, Nofiana, Sajidan \& Puguh. (2014). Pengembangan Instrumen Evaluasi TwoTier Multiple Choice Question Untuk
Mengukur Keterampilan Berpikir Tingkat Tinggi Pada Materi Kingdom Plantae. JURNAL INKUIRI, 3 (2): 60-74.

Mulyono, D. (2008). Pengukuran Dalam Bidang Pendidikan. Jakarta: Grasindo.

Ramirez, R. P. (2008). Creative Activities and Students' Higher Order Thinking Skills. . Journal of Education Quarterly, 66 (1):, 22-23.

Utomo, Tjipto \& Ruijter, K. (1989). Peningkatan dan Pengembangan Pendidikan: Manajemen Perkuliahan dan Metode Perbaikan Pendidikan. Jakarta: PT. Gramedia

Saputra, Hatta. (2016). Pengembangan Mutu Pendidikan Menuju Era Global: Penguatan Mutu Pembelajaran dengan Penerapan HOTS (High Order Thinking Skills). Bandung: SMILE's Publishing.

Thomas, R.G. \& Litowitz, L. 1986. Vocational Education and Higher Order Thinking Skills: An Agenda for Inquiry. Minnesota University: St. Paul Minnesota Research \& Development Center for Vocational Education.

Wildan, Aliefman, Supriadi. (2018). Sosialisasi dan Pendampingan Siswa Madrasah Aliyah Negeri I Mataram dalam Mengurangi Laju Pemanasan Global Tahun 2017 . Jurnal Pendidikan dan Pengabdian Masyarakat, 1 (1): 70-76. 